Climate change transformations in Nordic agriculture?

\author{
Juhola, Sirkku Kaarina
}

2017-04

Juhola, S K, Klein , N , Käyhkö , S J \& Neset, T S 2017 , ' Climate change transformations

in Nordic agriculture? ' , Journal of Rural Studies , vol. 51 , pp. 28-36 . https://doi.org/10.1016/j.jrurstud.2017.01.013

http://hdl.handle.net/10138/310513

https://doi.org/10.1016/j.jrurstud.2017.01.013

cc_by_nc_nd

acceptedVersion

Downloaded from Helda, University of Helsinki institutional repository.

This is an electronic reprint of the original article.

This reprint may differ from the original in pagination and typographic detail.

Please cite the original version. 


\title{
Climate Change Transformations in Nordic Agriculture?
}

\begin{abstract}
Climate change is expected to have negative impacts but also bring opportunities for agriculture and increase crop productivity in the Nordic countries. Little research has been conducted at the farmer level to identify what adaptation measures are being considered or already taken, and transformative these are. Based on semi-structured interviews with farmers and extension officers from two of the most fertile agricultural areas of Finland and Sweden, this study examines to what extent Nordic farmers are engaged in transforming their farming systems. The results show that some transformational changes are taking place already but most changes are incremental. Currently, farmers perceive agricultural policies and regulations as a greater challenge than climate change.
\end{abstract}

Keywords: Agriculture, vulnerability assessment, adaptation, climate change, Nordic 


\section{Introduction}

Adaptation in various societal sectors to the impacts of climate change is now considered inevitable (IPCC, 2014; Pielke et al., 2007), and this also includes agriculture (Tripathi et al., 2016). The most recent assessment of the Intergovernmental Panel on Climate Change (IPCC) states that climate change will have considerable impacts on agricultural production (IPCC, 2014, Aaheim et al., 2012). Transformations in agriculture are considered crucial, if food production is to increase in terms of quantity, as well as stability (Rippke et al., 2016). More profound transformations are likely to be necessary in areas, where warming is higher (Challinor et al., 2014) but changes in farming practices are likely to be required everywhere.

Nordic agricultural production might gain in importance globally in the future, as predictions reveal more positive effects than elsewhere in the world (Olesen et al., 2011; Rötter et al., 2012). The changing climate and weather variability are expected to contribute to a longer growing season, providing an opportunity for Nordic agriculture to increase crop yield and production (Bindi \& Olesen, 2011; Uleberg et al., 2014).

Agriculture as a sector is directly exposed to climate and weather changes, as well as indirectly through the global nature of agricultural markets, as climate impacts in one place affect market prices globally. Research so far has shown that non-climatic stimuli is important for famer decision-making (Uleberg et al., 2014) and that there is a myriad of reasons behind decisions, including attitudes, agricultural policy and market prices (Battershill and Gilg 1997; Bergevoet et al. 2004). Overall, the study of vulnerability and adaptation of agricultural systems is highly context and place-specific, and as a system would be vulnerable to specific climatic and nonclimatic stimuli and thus would adapt differently over time depending on its inherent characteristics and risks (Smit \& Wandel, 2006).

At the moment, there is little empirical research on how farmers in the Nordic countries consider their vulnerability to climate change, whilst research on other drivers exist (Strøm Prestvik et al. 2013). Farmers' perceptions of climate change have been shown necessary for adaptation to take place (Adib et al., 2016; Feola et al., 2015, Marshall et al., 2013, Wheeler et al., 2013), as it triggers the necessary changes that are needed for action, in addition to other factors (Mugi-Ngenga et al., 2016). Adaptation in agricultural systems has so far been slow (Lyle, 2015). Thus, learning how farmers perceive themselves to be impacted by climate and other change factors, and understanding under which circumstances farmers are able to transform their farming systems is crucial for both agricultural and climate change policy. 
So far, there is little empirical examination of adaptation measures that Nordic farmers are considering or have already implemented, nor how they themselves perceive their vulnerability and the need to transform their farming systems. Elsewhere, studies on farmer adaptation have focused on modelling approaches (Rodriquez et al., 2014, Leclere et al., 2012, Lehmann et al., 2013) with little empirical research on the ground. Research has also been carried out through large-scale surveys (Anton et al., 2013, Below et al., 2012), through policy documents and expert surveys (Bizikova et al., 2014), or with a combination of the above (Claessens et al., 2012, Schaap et al., 2013).

Farmers' perceptions of vulnerability are a crucial driver for farm level adaptation to take place and this adaptation leads to different degrees of change in the farming system. An examination of this allows one to see to what extent the sector is adapting to climate change. This qualitative empirical study focuses on Nordic agriculture in the counties of Östergötland in Sweden and Uusimaa in Finland, with both regions possessing a significant agricultural tradition and one of the most fertile agricultural areas in their respective countries. The study addresses the following research question: Are Nordic farmers taking transformative adaptation measures? We answer this question by examining the perceptions of vulnerability and the action Nordic farmers are taking through a qualitative case study of crop farmers.

\section{Climate change and transformations in Nordic agriculture}

When examining the role of climate change in Nordic agriculture, it is important to understand both the different dimensions of vulnerability, as well as any transformations that are taking place. In the following two sections, we present the theoretical underpinnings that guide our analysis in the results section.

\subsection{Vulnerability of Nordic agriculture}

Much of the impact of climate change on agricultural systems depends on complex interactions between physical factors, such as climate variability and climate change in ecosystems on the one hand and on socio-economic and cultural factors on the other (IPCC, 2014). Vulnerability ${ }^{1}$ research encompasses a large array of studies from different disciplines and scientific communities and, more recently, vulnerability assessments have become more policy-driven,

\footnotetext{
${ }^{1}$ Vulnerability is defined as a function of a system's exposure, sensitivity and adaptive capacity (Brooks, 2003; Füssel \& Klein, 2006; Smit \& Wandel, 2006), and can be understood as 'the degree to which a system is susceptible to, and unable to cope with, adverse effects of climate change, including climate variability and extremes' (IPCC, 2007, p.883).
} 
integrating more factors in the equation in order to inform and advise about feasible adaptation measures.

In this light, Smit \& Wandel (2006) propose a stakeholder-focused vulnerability assessment that contributes to the understanding of the decision-making process in the context of practical adaptation to climate change and variability. The authors state that one characteristic of such an approach "is that the researcher does not presume to know the exposure and sensitivities that are pertinent to the community, nor does the research specify a priori determinants of adaptive capacity in the community. Rather, in this approach these are identified from the community itself" (Smit \& Wandel 2006, p.288). This is in contrast to literature that focuses on systemic and often quantitative analyses of vulnerability of crops or the farming systems themselves (Eza et al., 2015; Bär et al., 2015).

Previous studies suggest that Nordic agricultural systems are predicted to be further exposed to increased temperature, especially during winter and to increased precipitation levels, as well as to an increase in temperature and precipitation variability and more frequent occurrence of extreme weather events, such as heat waves and heavy rainfalls (Bindi \& Olesen, 2011; Olesen et al., 2011; Himanen et al., 2013; Uleberg et al., 2014). These changes are expected to have positive effects in terms of increased yield potential, introduction of new crops but also negative effects on Nordic agriculture (Bindi \& Olesen, 2011; Olesen et al., 2011; Rötter et al., 2012; Uleberg et al., 2014).

With an increase in temperature, especially in the winter, and increased precipitation in the spring and summer, it is likely that the growing season enables more harvests and thus increasing the yield productivity (Fogelfors et al., 2009; Uleberg et al., 2014). However, these climatic changes can also bring an increase in pest attacks and diseases, difficult overwintering conditions and flooding, causing for instance difficult harvest conditions in autumn (Fogelfors et al., 2009; Uleberg et al., 2014).

In terms of sensitivity of Nordic agriculture, previous research has focused on crop yields and production levels in physical impact assessments, (local or regional) farm/management/practical level, and (national or international) policy or sectorial level (Smit et al., 1996; Howden et al., 2007; Reidsma et al., 2010). The results have shown that there are sensitivities in terms of growing conditions for particular crops. Also, Iglesias et al. (2012, p.165) state that "farming involves not only the production of crops and livestock, but also the management of people, supply chains, markets, building and transport infrastructure, and insurance. These indirect impacts of climate change in connected areas can have cumulative effects alongside the changes in crop productivity at farm level". Here, the role that global markets play in agriculture should not be ignored as significant driver of farmer decision- 
making. Impacts of climate change elsewhere can affect the markets and influence the decisions farmers make in other countries. In other words, farming should not be reduced to its crop and livestock productivity but it involves the subtle management of different farm factors and operations that are also sensitive to climate or weather changes and to non-climatic factors (Smit et al., 1996).

In addition to climatic factors, the agricultural sector is exposed to non-climate related factors, which can be significant (Smit et al., 1996; Smit et al., 2000; Smit \& Skinner, 2002; Fogelfors et al., 2009; Rehman et al., 2014; Uleberg et al., 2014). As Rehman et al. state, agriculture "is influenced by market fluctuations, national and international policies, practices in management, trading terms, technology availability, biophysical factors, etc.” (Rehman et al., 2014, p.242). In the European context and relevant to this case study, the European Union (EU) Common Agricultural Policy (CAP) is one of the major policy instruments that influences agricultural trends with subsidies, financial support and rural development programs to drive for instance agriculture towards more organic practices (Bindi \& Olesen, 2011). These non-climatic factors, socio-economic and institutional circumstances are constantly changing and the agricultural sector needs to adapt to these external systems, too (Smit \& Skinner, 2002; Adger et al., 2005; Kvalvik et al., 2011; Himanen et al., 2013).

\subsection{Adaptation and transformations in Nordic Agriculture}

Several adaptation practices have been identified that have the potential to reduce the vulnerability and enhance the adaptive capacity of the agricultural and farm systems in the context of Sweden and Finland (Fogelfors et al., 2009; Bindi \& Olesen, 2011; Olesen et al., 2011; Himanen et al., 2013; Uleberg et al., 2014). Adaptation options, such as the introduction of new crop species into the crop rotation, development of irrigation and drainage systems, changes in the cultivation timing, adjustments in the use of crop protection and in fertilization practices have been observed and identified in the agricultural sector (Smit \& Skinner, 2002; Olesen et al., 2011; Uleberg et al., 2014).

Adaptation to climate variability/weather variability is important in the context of agriculture (Smit et al., 1996; Smit \& Skinner, 2002; Howden et al., 2007; Kvalvik et al., 2011; Rickards $\&$ Howden, 2012) and "direct climate change impacts are difficult to separate from annual variability in growing conditions" (Kvalvik et al., 2011, p.32). The ability to respond to seasonal and yearly changes is crucial and the capacity to respond short-term is linked to capacity to respond in the long-term. Therefore, long-term climate trends, as well as short-term weather variability, should be accounted for in an assessment and analysis of the adaptation process and decision-making at farm management level of agricultural systems. 
Furthermore, several studies point out that agricultural systems and particularly farm-level systems are complex, influencing and influenced by multiple factors and others systems. It is unlikely that the adaptation decisions are only made with regards to climate change and/or climate variability (Smit \& Skinner, 2002; Smit \& Wandel, 2006). In effect, Smit \& Skinner (2002) argue that within agriculture, 'most adaptation options are not discrete technical measures likely to be undertaken specifically with respect to climate change. Rather, they are modifications to on-going farm practices and public level policies with respect not only to climate change but also to climatic variability and extremes, and other political, economic and social conditions' (Smit \& Skinner, 2002, pp.105-106), for example the CAP in this study.

However, this existing literature does not go into detail to analyse the types of adaptation measures farmers employ and how transformative these measures are. In recent years, the literature on adaptation to climate change has established numerous typologies in order to classify different adaptation measures (Smit et al., 2000; Smit \& Skinner, 2002; Smit \& Wandel, 2006; Rickards \& Howden, 2012). We argue that for the purposes of our analysis, the recognition of the different ways in which adaptation can take place is important. In the literature, adaptation measures have been differentiated by 1) the aim of the adaptation measure, and 2) the degree, as incremental, systemic or transformational adaptation (Smit et al., 2000; Smit \& Skinner, 2002; Smit \& Wandel, 2006; Rickards \& Howden, 2012).

First, the aim of adaptation relates to the objectives of the measures that are taken and it is possible to identify categories based on the intended outcome of the measure (Massey and Bergsma, 2008; Juhola, 2013). First, a farmer can take a measure to reduce the risk of climate impacts, e.g. structural protection from flooding. Second, improvement in coping capacity implies a measure that enhances the ability to deal with climate impacts as they are happening, e.g. dealing with the floodwater. Third, enhancement of adaptive capacity is a measure that increases the ability to deal with climate impacts in the long-term, e.g. enhancing the ability to deal with flood risk. Finally, measures can be adopted to take advantage of the opportunities that climate change brings. Increases in agricultural production are often discussed in relation to this (Wiréhn et al., forthcoming).

Second, it is important to examine the degree to which an adaptation measure affects the farming system. Acknowledging that it is difficult to draw boundaries clearly, both conceptually and in practice, Rickards and Howden (2012) propose a three level scale: incremental, systemic and transformational adaptation.

Incremental adaptation implies changes within the system, whereby most of its functions continue in their pre-existing trajectory. Some elements of the system change but the integrity of the system remains as it was before. Rickards and Howden, drawing on an agricultural 
example, consider changes in planting times, row spacing or water and nutrient management as incremental adaptation.

The second level of adaptation is termed as systems adaptation. This implies changes to an existing farm system that changes some fundamental features of the system. For example, these can include a change from livestock farming to cropping or vice versa, diversification, or the introduction of new crop species altogether. Farmers can choose specific crops species because of their characteristics suit new climatic conditions.

Transformational adaptation, argued by Rickards and Howden, changes more of the system than the remaining parts. An example of this would be to diversify towards off-farm activities or to change the locations of agricultural activities significantly. This can include changes in the goal of activities, creating a major change in land use and/or employment through trying to do more or something different and /or changes in location of an agricultural activity and/or agriculturalist.

\section{Case study and methods}

The Nordic countries were chosen as a case study area for two reasons. First, because the literature suggests that changes may bring conditions that are more favourable to the Nordic countries but it depends on individual farmers' decisions whether these are taken advantage of or not. Second, there are no empirical farm level studies on adaptation that assess the degree to which farmers are transforming their farms. The regions of Östergötland and Uusimaa were chosen because of their role in national agricultural production, representing fertile areas, see Table 1. The aim is not to compare the vulnerability of farmers in these two regions but rather to gain a better understanding of farm-level vulnerability, adaptation measures and the transformation taking place in Northern Europe.

Table 1. Case study details.

\begin{tabular}{|l|l|l|}
\hline & Uusimaa & Östergötland \\
\hline Location & South of Finland & South-East of Sweden \\
\hline Land area $\left(\mathrm{km}^{2}\right)$ & 9097 & 10562 \\
\hline $\begin{array}{l}\text { Agricultural land area }(\% \text { of } \\
\text { land area })\end{array}$ & 19 & 23 \\
\hline
\end{tabular}




\begin{tabular}{|l|l|l|}
\hline Forest (\% of land area) & 66 & 55 \\
\hline Coastline $(\mathrm{km})^{2}$ & 1100 & 738 \\
\hline Main crops (excluding fodder) & spring wheat, barley, oats & $\begin{array}{l}\text { winter wheat, potato, spring } \\
\text { barley }\end{array}$ \\
\hline Average farm size $(\mathrm{Ha})$ & 46 & 347 \\
\hline Dominating soil types & clayey soil, clayey silt soil & clayey soil, sandy soil \\
\hline Climatological conditions & $\begin{array}{l}\text { Warm humid continental } \\
\text { climate }\end{array}$ & $\begin{array}{l}\text { Warm humid continental } \\
\text { climate }\end{array}$ \\
\hline Climate change scenarios & $\begin{array}{l}\text { Temperatures and } \\
\text { precipitation rise, snow } \\
\text { cover and frost decrease, } \\
\text { winters become darker, } \\
\text { changes become greater in } \\
\text { the winter than in the } \\
\text { summer }\end{array}$ & $\begin{array}{l}\text { prowing season, increased } \\
\text { cloudburst, milder winters }\end{array}$ \\
\hline
\end{tabular}

In order to get a better understanding of the impact of climate change within agricultural management, a qualitative approach was chosen to gain in-depth and detailed information from farmers and extension officers. Semi-structured interviews were used with open-ended questions so that the respondents could elaborate their points of interests (Denscombe, 2007) and expand on the description of their experiences and points of view regarding adaptation. Interview guides followed the main categories of how climate change vulnerability is defined. The respondents were selected by first using a theoretical sampling design and then by "snowball" design (Warren, 2001, p.87). This resulted in a sample of five agricultural officials from different county institutions and five farmers in Östergötland and six officials and seven farmers in Uusimaa (see Table 2 below).

The interviewed officials (county officials, agricultural advisors and representative of farmers' union) were experienced with adaptation and had first-hand knowledge about both farm-level adaptation and the policies guiding adaptation measures. All interviewed farmers were active farmers of large main crop farms in the study areas. They cultivated at least one of the main

\footnotetext{
${ }^{2}$ Both regions have extensive coastline that also affects the agricultural activities in the region.
} 
crops of the region (see Table 1) and crop husbandry was their main activity, both regions being crop husbandry intensive. Other crops that farmers were cultivating included a) rye and green pea in both regions, b) rape, triticale, flax, organic animal fodder, field bean and vegetables in Östergötland, and c) turnip rape, buckwheat, malt wheat, malt barley, cumin, animal fodder, hay, pasture, fava bean, apple and strawberry in Uusimaa. Other sources of income the interviewees stated included forestry and husbandry of cattle, pig and organic poultry, which are typical to both regions. The farm size ranged from 210 ha to 640 ha in Sweden and from 80 ha to 360 ha in Finland. The climatic conditions of these two counties falls within the warm summer and humid continental climate according to the Köppen climate classification (Kottek et al. 2006).

Table 2: List of interviewees

\begin{tabular}{|l|l|l|}
\hline & Extension Officers & Farmers \\
\hline \hline Swedish interviewees & 2 County Officials & $\begin{array}{l}\text { 2 Organic and Conventional } \\
\text { Farmers, mainly wheat }\end{array}$ \\
\cline { 2 - 3 } & 2 Agricultural Advisors & $\begin{array}{l}\text { 2 Conventional Famers, } \\
\text { mainly potatoes, wheat and } \\
\text { barley/rye }\end{array}$ \\
\cline { 2 - 4 } & $\begin{array}{l}\text { 1 Representative of a Farmers } \\
\text { Fnion }\end{array}$ & $\begin{array}{l}\text { 1 Conventional Farmer, } \\
\text { mainly wheat and vegetables }\end{array}$ \\
\hline & 2 County Officials & $\begin{array}{l}5 \text { Conventional Farmers, } \\
\text { mainly oat, wheat, rye and } \\
\text { barley }\end{array}$ \\
\cline { 2 - 3 } & 2 Agricultural Advisors & $\begin{array}{l}\text { 1 Organic Farmer, mainly rye } \\
\text { and wheat }\end{array}$ \\
& $\begin{array}{l}\text { 2 Representatives of Farmers } \\
\text { Union }\end{array}$ & $\begin{array}{l}\text { 1 Conventional Farmer, } \\
\text { mainly strawberries and } \\
\text { varying grains }\end{array}$ \\
\cline { 2 - 3 } & &
\end{tabular}

Findings were analysed in the light of the research question, interpreted and discussed in relation to previous studies and theories (Berg, 2009; Creswell, 2014). Content analysis was chosen as the analysis method and all transcripts were further coded in order to identify themes/sub-categories, as well as relevant sentences coming up from the interviews that fitted the analytical categories or the inductively identified grounded categories discovered while 
coding the text (Berg, 2009; Creswell, 2014). The resulting table of categories, themes and subcategories were then organised and patterns and relationships between them were identified.

\section{Results}

\subsection{Vulnerability of Nordic farmers}

All of the interviewed officials, advisors and farmers were familiar with climate change and its projected changes on agriculture in the regions, and observations related to potential changes were in line with those identified in the existing literature.

The farmers mentioned a number of climate or weather-related features that agriculture in Östergötland and Uusimaa is exposed to, water being a major element of exposure. The majority of respondents considered the agricultural system sensitive primarily at the crop but also at the cultivation level. The respondents noted the effects of temperature increase, frequently describing experiences related to this change. Most respondents mentioned their expectation of drier summers and milder winters to come in the future. Consequently, farmers expressed a concern about an increasing presence of pests, plant diseases, harmful fungi and weeds. All respondents perceived this indirect climate temperature-related exposure to pests and diseases as a significant threat in the future.

More than half of the respondents also mentioned that this challenge of facing greater variability was accompanied by an additional challenge of increasing unpredictability and uncertainty about these weather and climate conditions in the future. On the other hand, several respondents described certain positive aspects of the changing climate. Some farmers and advisors talked about a longer growing season, enabling the cultivation of new sorts of crops, such as maize, and resulting in higher crop yield.

Sensitivity of the farm was also of concern. Respondents in both countries indicated that an abundance of water during harvesting time would put an increasing pressure on the drying capacities of farms and increase the workload of farmers. Farmers described their livelihoods as sensitive systems, due to their high dependency on the soil conditions, as well as increasing farm size, which makes every operation more time-consuming as larger areas need to be covered.

In addition to climate-related factors, the respondents also stated that non-climatic factors related to the wider context affected the vulnerability of agriculture. The perceived unpredictability of changes in EU and national legislation and irrelevancy of the regulations in their national or individual farm context were a concern for most of the respondents. 
Most of the farmers run their farms with economic success in mind. This means ensuring access to financial grants and subsidies, and avoiding negative sanctions, which sometimes resulted in undertaking farming measures that they thought were not in line with good farmer skills. According to the respondents, this meant that fields are cultivated crops and methods that do not produce the best yield or are not optimal for soil fertility. All farmers recognised themselves belonging to some peer-community (e.g. neighbour network, local producers' organisation, regional union, organic farmers' union) where they share experiences and knowledge. Farmers mostly used advisory services for advice to tackle changing policies and regulations.

\subsection{Adaptation measures}

We identified adaptation measures (total of 50 measures) related to all four aims discussed by the farmers, and the types of measures ranged from incremental changes to transformational.

In terms of reduction of risk (see Figure 1.), we identified 15 measures that were described to reduce the risks from three climatic stimuli: increased precipitation, increased climate variability and finally climate change on a more general level as a future unknown. Overall, the majority of the measures focused on incremental changes, for example, dealing with increased precipitation by avoiding unnecessary driving or using lighter machines, and changing the timing of framing operations due to climate variability. Systemic changes were related to changing from conventional farming to organic or farming practices that change the way the farm operates. Only two transformative measures were identified: a move away animal husbandry altogether, in order to reduce workload as this was seen as way to conserve resources and reduce risk, or the construction of buffer zones on farms that changes the ecosystems services provided by the farms.

[Figure 1 here]

Increasing coping capacity, in the face of three different climate stressors: longer growing season, increased climate variability and increased precipitation (See Figure 2), was undertaken with eight measures. Given that coping capacity is necessary for short-term events, the high number of incremental measures is not a surprise. The farmers mentioned the management and adaptation of water facilities to the changes in water quantity, either an increase or lack of water, as important. Indeed, all farmers and three of the other agricultural stakeholders brought up adaptation measures regarding the drainage system in the fields and by updating it with a better pipe system. 
Most of the farmers talked about changing crops or leaving them unharvested due to climate variability. For example, one of the officials estimated that many farmers have changed spring wheat and fava bean to barley and pea, resulting in an oversupply of barley in the spring of 2015, when the onset of spring was described as late. Three of the respondents had left crops unharvested in Uusimaa because farmers considered this more cost effective than harvesting on wet fields due to the risk of breaking the machines or severely packing the soil. Other alternatives that the farmers mentioned included leaving bales on the fields instead of gathering them on the sides of the fields and not tilling in autumn when the field are too wet.

[Figure 2 here]

Increasing adaptive capacity differs from coping capacity in that the measures that are planned and carried out support the ability of the farmer to carry out adaptation in the long term. Out of all four types of adaptation, most measures, 27, were identified in this category (see Figure 3). There are four climate stressors for which these kinds measures were undertaken for: climate variability, a longer growing season, increased precipitation and the protection of the watercourse. More systemic (17) and transformational (3) measures were identified in this category than the previous two.

Farmers in both countries stressed the fact that the farmers gradually update the drainage system usually once in a generation because it is a very expensive action and therefore usually planned to handle the water levels for the next 30 to 50 years. The adaptation by constructing trenches around agricultural fields was another measure discussed in Östergötland but considered too costly at the time. Many of the farmers repaired and adjusted the subsoil drainage in parts, as a necessary adaptive measure in Uusimaa. Two of the respondents had renewed the whole subsoil drainage system (by digging new pipelines crosswise to old ones on top of them) but both of them had failed to adequately enhance the drainage on the field with the measure.

Other practical measures that the farmers mentioned were deeper ploughing, or employment of structural soil liming on soils, which were identified as sensitive to excessive amounts of rainwater. This measure intends to improve the soil's structure in order to enable the excess of water to go through the soil faster and with minimized levels of phosphorus to prevent nutrient leakage. In this respect, the adaptation initiative generates a positive synergy as it benefits both the farming business and the environment and can lead to capitalisation on climate change.

Farmers considered investment in more tractors as a good strategy in Östergötland. Farmers thought them to have more capacity and to enable faster action in the field within shorter timewindows when the conditions are optimal. This strategy has its downside as the big machines are costly and farmers usually buy them collectively. This decreases the flexibility regarding 
timing when owners might want to use them simultaneously. Finnish respondents highlighted the lightness and pressure impact spreading feature of the machinery (wider or double tires), rather than its effectiveness. Finally, another technological investment is a drying house to dry the increasingly wet wheat that comes in from the harvest or drip irrigation. Among the alternative ways of enhancing the adaptability of local agriculture, farmers frequently mentioned the improvement of the soil structure in both countries, particularly in relation to the handling of machines and vehicles to avoid soil compaction as much as possible to adapt to wetter conditions.

[Figure 3 here]

Finally, capitalising on climate change implies measures that allow farmers to increase their productivity in the longer term. There are three climatic stressors that farmers consider it possible to take advantage of: longer growing season, increased precipitation and climate change in general. There is only one incremental measure, whilst there are seven systemic measures and two transformational measures (Figure 4). This implies that to take advantage of climate change, larger changes are necessary than what is generally undertaken.

A frequently mentioned adaptation option was to cultivate different crops, such as maize, and to grow crops that are more resilient to extreme weather and more tolerant to very wet or dry conditions. Some farmers mentioned diversification as an adaptation strategy. The crop-related adaptation measures most of them had taken and were planning to take in future included winter grains, choosing different crop varieties, green fallows, buffer zones and nature conservation fields, which also have other ecosystem benefits.

Some of the Swedish farmers have an irrigation system but only for the land on which they grow potatoes. One farmer explained that he invested in an irrigation dam but another farmer stated that he only considered it:

I believe that this trend of having periods of cloudburst versus drought will increase and the same as with drainage, we must upgrade the systems and I have even thought of building a dam down here but I thought that the price scared me a little bit too much. (Farmer 3)

In fact, all the other respondents who mentioned irrigation as potential adaptation stated that currently implementing an irrigation system on cereals was not profitable enough.

In relation to the farm management scale, some respondents named such adaptive measures as changing the production structure or sector. One of the officials deliberated that there are two 
major directions for the Uusimaa agriculture in future and that the adaptation measures are path-dependent on them:

"[I]n the time period of 2050-2100 the farm units will become fewer, total field area will remain the same and farm sizes will increase. The ways that farmers will operate with the increasing field sizes can be seen from different viewpoints. Production can either be intensified from the production side and by increasing the labour force, which requires personnel management. On the other hand there is the extensification of production, which means that fairly large areas could be left as fallow." (Official 4)

The quote corresponds to the perceptions of most officials in Finland in that the average farm size is expected to grow in the future, similarly to Sweden where the average size is already larger. Some of the officials were talking about the lack of a broader vision, shattered actor network of Uusimaa agriculture sector as a vulnerability-increasing factor, and therefore saw long-term planning with different stakeholders as a necessary adaptive measure. Dealing with the markets was also seen as something that can be affected with the right type of adaptation measures.

[Figure 4 here]

\section{Discussion}

To answer the first research question, the findings show that the decision-making process that farmers, in collaboration with extension officers, undertake in order to adapt the farm system to climate change and weather variability is a complex one. The respondents described agriculture in both Uusimaa and Östergötland as a sector that is becoming more time-pressured and in which the biggest challenge is to be attentive to and to follow and adapt to increasingly unpredictable and more extreme weather conditions. This is in order to minimise the negative impacts on the machines and working conditions and to avoid negative effects on crop yield, crop quality and soil structure.

The findings of this study, which relate to the farmers' perceived exposure and sensitivity to agriculture, are consistent with previous vulnerability studies (Fogelfors et al., 2009; Bindi \& Olesen, 2011; Kvalvik et al., 2011; Olesen et al., 2011; Himanen et al., 2013; Uleberg et al., 2014; Länsstyrelsen Östergötland, 2015). Farmers consider their greatest challenges to arise from increases in intense rainfalls, persistent wet/dry periods and an increase in temperature that causes pest attacks and diseases to become more frequent. These can further lead to difficult 
soil management and harvesting conditions, and an increasing use of crop protection. Earlier studies also reported the opportunities of a longer growing season.

The officials' and advisors' perceptions of actual and future climate changes and adaptation did not differ much from those of the farmers. The perceptions of farmers were based more on personal, peer experiences and they were more connected to practical and concrete actions on the farm than those of the officials were. All interviewed officials and advisors had a good overview of the regional agricultural sector, and some were practicing farmers themselves. There were individual differences on perceptions of necessary adaptation measures too. For example, the farmers' union representatives had stronger emphases on securing the farmers income and the profitability of farming than others, whereas the official responsible for environmental subsidies emphasised the environmental conservation aspects on adaptation.

Addressing the second research question, the findings related to the aim and degree of transformation yield interesting results. Firstly, the adaptation actions identified in this study largely correspond with those identified in the literature. The interviewees described measures that they have taken in response to the weather and climate variability. These included taking care of soil structure and avoiding soil compaction in general, and more specifically by minimizing driving on the fields and using lighter machinery, enhancing the drainage, ploughing deeper, using lighter tillage and direct sowing, changing crops in the beginning of season and leaving crops unharvested and changing into more profitable crop. For example, the improvement and maintenance of water facilities, such as updating drainage systems or enlarging trenches; changes of tillage practices to improve or maintain the quality of soil and water, and investment in technology and machines have previously been discussed (Smit et al., 1996; Kvalvik et al., 2011; Olesen et al., 2011; Iglesias et al., 2012; Uleberg et al., 2014; Länsstyrelsen Östergötland, 2015).

Measures to improve their capacity to deal with change in the longer term included changing into more resilient crops, planning for two growing seasons, improving their risk management by increasing their crop selection; invest on drying capacity and increasing the permanent vegetative coverage. These findings support earlier studies' findings, i.e. cultivating new and more resilient crops, as well as changes in the timing and practices of farm operations (Fogelfors et al., 2009; Anwar et al., 2012; Himanen et al., 2013). Interestingly, the farmers also identified measures that they could take, if there were no economic or policy limitations. These included updating and improving the whole drainage system, taking up irrigation, adapting the watercourses and shaping the fields. 
To contribute to literature, our analytical approach to identifying the aim and degree of adaptation allows us to assess how farmers are considering transformations in the face of climate change.

In terms of the aim of adaptation, most of the measures identified were related to increasing adaptive capacity in the long term and these measures were related to cropping practices, as well as general farm management. It can also be seen from the analysis that these measures were more systemic and transformational, rather than incremental. This suggests that farmers that are aware of the risk associated with climate change have implemented or are considering measures that are more than incremental in terms of adaptation in the long term. Overall, fewer measures aimed at reducing risks and increasing coping capacity in the short term. These were mainly incremental actions. When examining these measures, it appears that these are common actions taken to deal with climate variability and farming conditions in general.

Whilst the findings show that Nordic farmers are engaged in adaptation and most of the measures indicate at least a systemic degree of change, they did not consider climate change of an immediate concern. In fact, respondents considered other factors to influence their decisionmaking more at the moment, feeling more affected by the challenges of policies and financial markets, rather than by a changing climate and increased weather variations, as has also been found in previous studies (Kvalvik et al., 2011; Himanen et al., 2013). There was an expectation that this could change in the future but that other factors in addition to climate change will continue to affect decisions.

The results of this study indicate that, on the one hand, the farmers tend to evaluate whether or not to adapt in a certain way following a decision-making process that consisted of making trade-offs between different alternatives. On the other hand, the officials and agricultural advisors tend to evaluate an adaptation measure in broader terms, including also its environmental benefits and its contribution to climate change mitigation, for example. Consequently, it can be argued that, as the literature states, the successfulness or the criteria for efficient adaptation is subjective, and thus depends on from which perspective one views the objective of an adaptation measure (Smit \& Skinner, 2002; Adger et al., 2005).

\section{Conclusion}

This study asks the question whether Nordic farmers are taking transformative adaptation measures. By choosing the particular contexts of Östergötland and Uusimaa and by interviewing relevant stakeholders, the results depict farms as climate-vulnerable and 
constantly adapting systems, with their crop fields managed by farmers working in collaboration with each other and with extension officers.

Following a conceptual framework based on IPCC definitions, the results of this study show perceptions of a system exposed to more intense rainfalls, greater weather variability and an expected increase in pest attacks and diseases. The study also describes a farming system with crops, soil structure, and farm infrastructures that are increasingly sensitive to more unpredictable weather conditions. Although being a climate-vulnerable system, experiences show a greater challenge in adapting to strict policies, subsidies restrictions and the effect of global market prices than climate change for the time being. Thus, our results show that Nordic farmers perceive vulnerabilities but do not consider these significant enough yet to warrant immediate action. Other stressors, such as agricultural policy and market conditions are more influential. This finding raises up the further questions to what extent these other drivers have the potential hamper farmers' ability to adapt to climatic stimuli in the future, stressing the importance to understand more about the trade-offs involved.

Examining the aim and degree of adaptation, it appears that Nordic farmers are interested in building adaptive capacity through systemic changes, whilst also carrying out incremental changes to reducing risks and maintaining capacity to cope short term. Capitalising on climate change does not emerge as a priority and this could be due to the higher degree of transformation needed to achieve this, i.e. a transformation of the farming system. At the moment, farmers do not consider climate change as a strong enough driver to influence their decision-making, with agricultural policy and markets having a stronger impact.

Consequently, this study concludes that when focusing on the farm management level, the transformation of agricultural systems is in the face of not only climate change but also other factors, such as global markets. Whilst Nordic agriculture is considered to gain from climate change, it is important to recognise the context-specific nature of adaptation and the decision processes and motivations associated with it. Not all farmers are able to or interested in adapting to the same extent and it is important to see what incentives there may be to encourage this further.

A number of future directions for research emerge from this study. These include further questioning of farmer motivations for transforming their farming systems and the institutional and policy support that is effective within and outside the sector to achieve this. Also, very little is known about the effectiveness of adaptation measures in the long term and whether they lead to positive outcomes in farming systems or maladaptive outcomes. Therefore, further research 
on the sector is necessary in the Nordic countries to assess its ability to deal with climate change in the future.

\section{Acknowledgements}

This manuscript acknowledges support from the Nordic Centre of Excellence NORD-STAR.

\section{References}

Aaheim, A., Amundsen, H., Dokken, T., and Wei, T., 2012. Impacts and adaptation to climate change in European economies. Global Environmental Change 22, 4, pp. 959-968.

Adger, W.N., Arnell, N.W. and Tompkins, E.L., 2005. Successful adaptation to climate change across scales. Global Environmental Change, 15, pp.77-86.

Abid, M., Schilling, J., Scheffran, J., and Zulfiqar, F., 2016. Climate change vulnerability, adaptation and risk perceptions at farm level in Punjab, Pakistan. Science of the Total Environment 547, pp. 447-460.

Antón, J., Cattaneo, A., Kimura, S., and Lankoski, J., 2013. Agricultural risk management policies under climate uncertainty. Global Environmental Change 23, 6, pp. 1726-1736.

Anwar, M.R., Liu, D.L., Macadam, I., Kelly, G., 2012. Adapting agriculture to climate change: a review. Theoretical and Applied Climatology 113, pp.225-245.

Battershill, M.R.J. and Gilg, A.W., 1997. Socio-economic constraints and environmentally friendly farming in the southwest of England. Journal of Rural Studies 13, 2, pp. 213-228.

Below, T. B., Mutabazi, K. D., Kirschke, D., Franke, C., Sieber, S., Siebert, R., and Tscherning, K., 2012. Can farmers' adaptation to climate change be explained by socio-economic household-level variables? Global Environmental Change 22, 1, pp. 223-235.

Berg, B.L., 2009. Qualitative Research Methods for the Social Sciences, Pearson, Boston MA, 7 th edition.

Bergevoet, R.H.M., Ondersteijn, C.J.M., Saatkamp, H.W., van Woerkum, C.M.J., Huirne, R.B.M., 2004. Entrepreneurial behaviour of Dutch dairy farmers under a milk quota system: Goals, objectives and attitudes. Agricultural Systems 80, pp. 1-21. 
Bindi, M., Olesen, J.E., 2011. The responses of agriculture in Europe to climate change. Regional Environmental Change 11, pp.151-158.

Bizikova, L., Crawford, E., Nijnik, M., and Swart, R., 2014. Climate change adaptation planning in agriculture: processes, experiences and lessons learned from early adapters. Mitigation and Adaptation Strategies for Global Change 19, 4, pp. 411-430.

Brooks, N., 2003. Vulnerability, risk and adaptation : A conceptual framework. Tyndall Centre for Climate Change Research, Norwich, University of East Anglia 38(November), p.20. Available at: papers2://publication/uuid/D2016620-F4DE-4C0A-BE4B-78E8F2701438.

Bär, R., Rouholahnejad, E., Rahman, K., Abbaspour, K. C., and Lehmann, A., 2015. Climate change and agricultural water resources: A vulnerability assessment of the Black Sea catchment. Environmental Science \& Policy 46, pp. 57-69.

Challinor, A. J., Watson, J., Lobell, D. B., Howden, S. M., Smith, D. R., and Chhetri, N., 2014. A meta-analysis of crop yield under climate change and adaptation. Nature Climate Change 4, 287-291.

Claessens, L., Antle, J. M., Stoorvogel, J. J., Valdivia, R. O., Thornton, P. K., and Herrero, M., 2012. A method for evaluating climate change adaptation strategies for small-scale farmers using survey, experimental and modeled data. Agricultural Systems 111, pp. 85-95.

Creswell, J.W., 2014. Research Design: Qualitative, Quantitative, and Mixed Methods Approaches, 4th edition, Sage Publications, Thousand Oaks, CA.

Denscombe, M., 2007. The good research guide for small-scale social research projects. London, McGraw-Hill Education (UK).

Dolan, H., Skinner, M.W. and Bryant, C.R., 2001. Adaptation to climate change in agriculture : Evaluation of Options, Occasional Paper, 26.

Eza, U., Shtiliyanova, A., Borras, D., Bellocchi, G., Carrère, P., and Martin, R., 2015. An open platform to assess vulnerabilities to climate change: An application to agricultural systems. Ecological Informatics 30, pp. 389-396.

Feola, G., Lerner, A. M., Jain, M., Montefrio, M. J. F., and Nicholas, K. A., 2015. Researching farmer behaviour in climate change adaptation and sustainable agriculture: Lessons learned from five case studies. Journal of Rural Studies, 39, pp. 74-84.

Fogelfors, H. et al., 2009., Strategic Analysis of Swedish Agriculture in a time of change, Uppsala. Available at: http://pub.epsilon.slu.se/4626/1/fogelfors_et_al_100325.pdf. 
Füssel, H.M.., Klein, R.J.T., 2006. Climate change vulnerability assessments: An evolution of conceptual thinking. Climatic Change, 75, pp.301-329.

Himanen, S.J., Hakala, K. and Kahiluoto, H., 2013. Crop responses to climate and socioeconomic change in northern regions. Regional Environmental Change, 13, pp.17-32.

Howden, S.M., Soussana, J. F., Tubiello, F. N., Chhetri, N., Dunlop, M., and Meinke, H., 2007. Adapting agriculture to climate change. Proceedings of the National Academy of Sciences of the United States of America 104, 50, pp.19691-19696.

Iglesias, A., Quiroga, S., Moneo, M., and Garrote, L., 2012. From climate change impacts to the development of adaptation strategies: Challenges for agriculture in Europe. Climatic Change, 112, pp.143-168.

IPCC, 2014. Summary for Policy Makers. In: Climate Change 2014: Impacts, Adaptation, and Vulnerability. Part A: Global and Sectoral Aspects. Contribution of Working Group II to the Fifth Assessment Report of the Intergovernmental Panel on Climate Change, Cambridge University, Cambridge, United Kingdom and New York, NY, USA.

IPCC, 2007. Climate Change 2007: impacts, adaptation and vulnerability: contribution of Working Group II to the fourth assessment report of the Intergovernmental Panel.

Juhola, S. 2013. Adaptation to climate change in the private and the third sector: case study of governance of the Helsinki Metropolitan region. Environment and Planning C: Government and Policy, 31, 5, pp. 911-925.

Kottek, M., J. Grieser, C. Beck, B. Rudolf, and F. Rubel, 2006: World Map of the KöppenGeiger climate classification updated. Meteorol. Z., 15, 259-263. DOI: 10.1127/09412948/2006/0130.

Kvalvik, I., Dalmannsdottir, S., Dannevig, H., Hovelsrud, G., Rønning, L., and Uleberg, E., 2011. Climate change vulnerability and adaptive capacity in the agricultural sector in Northern Norway. Acta Agriculturae Scandinavica Section B _ Soil and Plant Science, 2011; 61: Supplement 1,27_37, (September), pp.37-41.

Lehmann, N., Finger, R., Klein, T., Calanca, P., and Walter, A., 2013. Adapting crop management practices to climate change: modeling optimal solutions at the field scale. Agricultural Systems 117, pp. 55-65.

Lewis-Beck, M., Bryman, A. E., and Liao, T. F., 2003. The Sage Encyclopedia of Social Science Research Methods. London, Sage Publications. 
Lyle, G., 2015. Understanding the nested, multi-scale, spatial and hierarchical nature of future climate change adaptation decision making in agricultural regions: a narrative literature review. Journal of Rural Studies, 37, pp. 38-49.

Länsstyrlesen Östergötland, 2015. Jordbruk och vattenmiljöer i ett förändrat klimat (JoVaK): Preliminär rapport, Norrköping.

Massey, E., \& Bergsma, E., 2008. Assessing adaptation in 29 European countries. Amsterdam: IVM. Free University of Amsterdam.

Mugi-Ngenga, E. W., Mucheru-Muna, M. W., Mugwe, J. N., Ngetich, F. K., Mairura, F. S., and Mugendi, D. N., 2016. Household's socio-economic factors influencing the level of adaptation to climate variability in the dry zones of Eastern Kenya. Journal of Rural Studies, 43, pp. 49-60.

Olesen, J.E., Trnka, M., Kersebaum, K. C., Skjelvåg, A. O., Seguin, B., Peltonen-Sainio, P., Rossi, F., Kozyra, J. and Micale, F., 2011. Impacts and adaptation of European crop production systems to climate change. European Journal of Agronomy, 34(2), pp.96-112. dx.doi.org/10.1016/j.eja.2010.11.003.

Pielke, R. Prins, G., Rayner, S., and Sarewitz, D., 2007. Climate change 2007: lifting the taboo on adaptation. Nature, 445, 7128, pp.597-598.

Rehman, R. Hamdani, A., Naseem, A., Ashraf, M., and Kazi, A. G., 2014. Scenario of Climate Change on the Context of Agriculture. In P. Ahmad \& M. R. Wani, eds. Physiological Mechanisms and Adaptation Strategies in Plants Under Changing Environment. New York: Springer, pp. 321-364. Available at: http://link.springer.com/10.1007/978-1-4614-8591-9.

Reidsma, P., Ewert, F., Lansink, A. O. and Leemans, R., 2010. Adaptation to climate change and climate variability in European agriculture: The importance of farm level responses. European Journal of Agronomy, 32, pp.91-102.

Rickards, L., Howden, S.M., 2012. Transformational adaptation: Agriculture and climate change. Crop and Pasture Science, 63, pp.240-250.

Rippke, U., Ramirez-Villegas, J., Jarvis, A., Vermeulen, S. J., Parker, L., Mer, F., Diekkruger, B., Challinor, A.J., and Howden, M., 2016. Timescales of transformational climate change adaptation in sub-Saharan African agriculture. Nature Climate Change. doi:10.1038/nclimate2947 
Rodriguez, D., Cox, H., and Power, B., 2014. A participatory whole farm modelling approach to understand impacts and increase preparedness to climate change in Australia. Agricultural Systems, 126, pp. 50-61.

Rötter, R.P., Höhn, J.G. and Fronzek, S., 2012. Projections of climate change impacts on crop production: A global and a Nordic perspective. Acta Agriculturae Scandinavica, Section A Animal Science, 62, pp.166-180.

Schaap, B. F., Reidsma, P., Verhagen, J., Wolf, J., and van Ittersum, M. K. 2013.

Participatory design of farm level adaptation to climate risks in an arable region in The Netherlands. European Journal of Agronomy, 48, pp. 30-42.

Smit, B. et al., 2000. An anatomy of adaptation to climate change and variability. Climatic Change, 45, pp.223-251.

Smit, B., McNabb, D. and Smithers, J., 1996. Agricultural adaptation to climatic variation. Climatic Change 33, pp.7-29.

Smit, B., Skinner, M.W., 2002. Adaptation options in agriculture to climate change. Mitigation and Adaptation Strategies for Global Change 7, pp.85-114.

Smit, B. \& Wandel, J., 2006. Adaptation, adaptive capacity and vulnerability. Global Environmental Change 16, pp.282-292.

Statistiska centralbyråns (SCB), 2013. Miljö - Statistisk årsbok 2013. 2013, 26 p.

Statistiska centralbyråns (SCB), 2002, Statistiska meddelanden, serie MI 50: Kust och stränder i Sverige, 19p.

Strøm Prestvik, A., Kvakkestad,. V., Skutevik, Ø., 2013. Agriculture and the environment in the Nordic countries. Policies for sustainability and green growth. TemaNord 2013:558, 103p. Tripathi, A., Tripathi, D. K., Chauhan, D. K., Kumar, N., and Singh, G. S., 2016. Paradigms of climate change impacts on some major food sources of the world: A review on current knowledge and future prospects. Agriculture, Ecosystems \& Environment, 216, pp. 356-373. Uleberg, E. Hanssen-Bauer, I., van Oort, B., and Dalmannsdottir, S., 2014. Impact of climate change on agriculture in Northern Norway and potential strategies for adaptation. Climatic Change, 122(I), pp.27-39.

Wheeler, S., Zuo, A., and Bjornlund, H., 2013. Farmers' climate change beliefs and adaptation strategies for a water scarce future in Australia. Global Environmental Change 23, 2, pp. 537-547. 
Wiréhn L. (forthcoming). Nordic agriculture under climate change - A review on challenges, opportunities and adaptation strategies for crop production. 